\title{
Use of Defamiliarization in College English Classes
}

\author{
Fuhua Liu \\ School of Foreign Languages, Dalian Jiaotong University, Dalian, Liaoning 116028, China
}

Keywords: defamiliarization, college English classes, environment defamiliarizaiton, identity defamiliarization, teaching method defamiliarization

Abstract: The paper is a detailed analysis of the application of "defamiliarization" technique to college English classes. After introducing the term "defamiliarization", the paper continues to illustrate how this technique can be applied to the learning and teaching practice from the perspectives of environment defamiliarizaiton, identity defamiliarization and teaching method defamiliarization.

\section{Introduction}

Originally, "defamiliarization" is a well-known literary term put forward by Russian formalist Viktor Shklovsky. Defamiliarization intends to turn the ordinary into the extraordinary. By turning something ordinary into something new, fresh and unique, the user of the technique can well attract the audience's attention and arouse their curiosity [1]. This useful technique can also be applied to our college English classes, as one of the most important factors that affect second language acquisition is students' duration of attention and intensity of interests. Therefore, to sustain students' attention and interests, college English teachers can use various "defamiliarizaiton" techniques including environment defamiliarizaiton, identity defamiliarization and teaching method defamiliarization.

\section{Body}

\subsection{Use of Environment Defamiliarization in College English Classes}

Students are definitely bored if they are immersed in the same environment every time they learn English in class. Students need to be constantly inspired to integrate into new environments created by the teachers or themselves. Environment change as an external factor often has very favorable impacts on students' learning efficiency and effectiveness. In a new learning environment, students tend to be more stimulated and active than in a conventional class. Often, students' impulse to change for the better results from the change of the environment.

The following are some practical tips that may be helpful to teachers willing to change the environment to encourage students' learning. First, traditionally, teachers stand in the front of the classroom, while students sit in rows. In a defamiliarized environment, teachers may arrange students around a table occasionally if possible instead of letting students sitting in rows. Teachers may sit casually around them. In this way, students may feel they have been treated equally. And 
this relaxing atmosphere enables students to speak out and actively get involved in a discussion in class.

In addition, teachers may use high-technology multi-media to provide the defamiliarized environment. For example, a teacher may use a voice bar through WeChat group or QQ group to communicate with his or her students after class. In this new environment, student may feel excited about the new learning experience and are likely to ask more questions than in a face-to-face traditional class. Through this new communication channel, the teacher must express his ideas very carefully. And students bear the same pressure of expressing themselves in an accurate manner. In a word, both sides may benefit from the defamiliarized environment.

Lastly, as teachers, there are many other things they can do to create environment defamiliarization. To begin with, sometimes even an occasional change of outfit may work well. Teachers may benefit a lot from dressing up for their classes in that they have gained not only self-esteem and self-confidence for themselves but respect and a sense of conformity from the students. Students required to dress in uniforms for a change for classes may become more self-disciplined and collectivism-oriented. Moreover, if teachers plan to use PowerPoint in class, they may ask students to pull together the curtains to calm down and darken the classroom. In this way, a temporary defamiliarized setting is created, and students get more focused and inspired in this defamiliarized environment. Finally, for an oral English class, teachers may even create a mobile defamiliarized learning environment. For example, an English teacher's class is about learning different trees. The teacher involved may apply for an outdoor oral class and organize the class in the botany garden.

\subsection{Use of Identity Defamiliarization in College English Classes}

First, teachers may create identity defamiliarization by giving students the opportunity to play the role of teachers. With a teacher sitting as audience, the student speaking on stage may feel fresh and excited, intending to show the best of him or herself in front of the teacher and his or her classmates. While the student is giving his or her show on stage, the teacher can calmly observe the student's performance from the perspective of a student. In this way, mutual communication can be achieved, leading to better mutual understanding between teachers and students. After the change of roles, teachers will ponder on how to teacher better, and students how to learn better.

Second, the adding of teachers also creates identity defamiliarization. If conditions permit, a teacher may invite a colleague, either native or foreign, to class. Most students will consider the invited teacher as a "guest" rather than "intruder", and they will try to leave favorable impressions on the "guest". The two teachers may co-lecture to create a unique talk-like atmosphere to hold students' interests. The guest may also take part in all class activities and offer specific instructions.

Third, for a language course, teachers should be encouraged to exchange their teaching objects on a regular basis. While it is practically impossible to change their teaching objects within a semester, it is highly advised to have teachers teach different students every semester. The new teachers for a new semester will make the students feel fresh and stimulated. 


\subsection{Use of Teaching Method Defamiliarization in College English Classes}

Teaching method defamiliarization is the most prominent technique employed by teachers out of the three. Traditionally, the teaching of English may involve warm-up, vocabulary illustration, detailed analysis of the text, structure analysis and so on. Students may easily get fed up with this conventional teaching method, and they really need something new and fresh to hold their attention and interests. Defamiliarization works very well in saving students out of this boring teaching.

First, teachers may achieve defamiliarization by changing teaching to part-testing, part teaching. For example, one of the CET 4 question types is "skimming and scanning", requiring students to identify the paragraph a statement comes from. The teacher in charge may make up several statements in advance and ask students to do the task in class. After the students finish the task, the teacher may give his or her explanation.

Second, role-play, oral presentation, dubbing, debate etc. are all typical defamiliarized teaching methods different from the traditional teaching methods. But as these teaching methods are used so often that the defamiliarization embodied by them seems to have become once again familiar to students. In this case, teachers need to come up with more creative ideas to keep the students' interests. For example, a teacher may ask students to make a dialogue, which seems to be a familiar method mentioned above, but if the teacher asks students to make a video clip of the dialogue, the defamiliarized effect is sure to be attained. Students may become greatly inspired by this new and challenging teaching method, and they may develop a keen interest in watching their own performance through the video clip. As the video clip is to be shown to the teacher and their classmates in class, they may rehearse a lot to make their performance perfect.

Third, to create teaching method defamiliarization, teachers may change their students into self-reflective learners [2]. That is, students begin to learn how to learn English well together with their teacher. They may do some research about language acquisition and apply the theories to their learning practice. Students may benefit even more from this defamiliarized activity, because they are supposed to learn how to learn before they learn what to learn. And how to learn a language is, to some extent, more important than what to learn.

\section{Conclusion}

After introducing the literary term "defamiliarization", the paper continues to explain in detail how the defamiliarization technique can be applied to the learning and teaching practice in college English classes. As for environment defamiliarization, teachers may arrange students in a classroom in new ways, use high-technology multi-media and make good use of other environment-changing techniques. The identity defamiliarization can be achieved by giving students the opportunity to play the role of teachers, adding teachers and changing teachers on a semester basis. To achieve teaching method defamiliarization, teachers may teach by part-testing, come up with creative ideas to improve the already defamiliarized teaching method and change their students into self-reflective learners. By creating various defamiliarization techniques for students, teachers will find students' learning and their teaching more stimulating and effective. 


\section{References}

[1] Zhu Gang. Literary Criticism in the 20th Century. Beijing: Beijing University Press, 2006.

[2] Shen Huina. "Defamiliarization” in Language Class Teaching. Journal of Fujian Institute of Education, 2018(5). 